\title{
GST in India: Expectations and Challenges
}

Dr. Ratul Mahanta ${ }^{\dagger}$

\section{Abstract}

India is ready to implement its "Goods and Services Tax (GST)" act from 1st April 2017. It is expected that GST will minimise all the loopholes of existing tax system in India. However, critics argue that the euphoria over GST camouflages the deadly assault to tax policy as a means of promoting equity and efficiency. This review on GST highlights the challenges over GST claims. It has been observed that to implement GST effectively, both centre and state have to go hand in hand.

Key words: Cascading Effect of Tax, Tax Buoyancy, Vertical Fiscal Imbalance, Make in India, India

\footnotetext{
${ }^{\dagger}$ Assistant Professor, Department of Economics, Gauhati University Guwahati, Email: mahanta_r@yahoo.com (C) 2016 Mahanta. This is an Open Access article distributed under the terms of the Creative Commons Attribution License (http://creativecommons.org/licenses/by/2.0), which permits unrestricted use, distribution, and reproduction in any medium, provided the original work is properly cited.
} 


\section{Introduction}

India faces a formidable challenge in developing an efficient tax structure as it has to generate sufficiently large revenue and incidental to this the government has to play a role as an instrument of granting social justice. Contrary to other developed nations, India relies more on indirect tax on consumption for revenue mobilisation, which is regressive in nature. On the other hand, direct tax is less buoyant (Mukherjee, 2015) and it is narrow in scope (Picketty and Qian, 2009) ${ }^{1}$. During the last five decades, Indian government had mobilised resources mainly from indirect taxes with some modifications from time to time. India's tax-GDP ratio is $16.6 \%$, which is much lower than Organisation for Economic Cooperation and Development (OECD) countries (34\%) and other emerging economies (21\%) (National Treasury, 2015). As a result, there is a need to streamline the existing tax structure. Recently, that is on 03 August 2016, the Government of India has taken a major step towards introducing 'Goods and Services Tax (GST)" for reforming indirect taxes by passing The Constitution (122nd Amendment) (GST) Bill, 2014 in the Rajya Sabha (the upper house of the Parliament of India). ${ }^{2}$ There have been massive amount of discussions and debates on the potential impact (both favourable and unfavourable) of GST. Here, I try to analyse whether GST could address the basic problems of equity and efficiency in India's tax system.

The discussion will consist of four sections. The next section highlight the genesis of GST followed by the third section which explain challenges ahead of GST while addressing the

\footnotetext{
${ }^{1} \mathrm{~A}$ tax is said to be buoyant if the tax revenues increase more than proportionately in response to a rise in national income or output (Belinga et al., 2014).

${ }^{2}$ The bill was passed in the Lok Sabha (lower house of the Parliament) on 06 May 2015 and again on 08 August 2016 (after it was passed in the Rajya Sabha) (The Constitution (One Hundred and Twenty-Second Amendment) Bill, 2014, Bill No. 192-C of 2014, available at:

http://www.prsindia.org/uploads/media/Constitution\%2 0122nd/Constitution\%20\%28122\%29\%20as\%20passed\% 20by\%20LS.pdf (accessed October 7, 2016).
}

fundamental issues of Indian Tax system. The last section gives the concluding remarks.

\section{Genesis of GST}

Major reform in Indian tax system was initiated first in 1986 when the government introduced Modified Value Added Tax (MODVAT). The idea behind modification of existing VAT was to introduce a tax based on value added rather than on final value of the transacted output. The motivation behind such modification was to minimise the 'cascading effect' ${ }^{3}$. However, the efficiency of MODVAT were often questioned on the ground that it compromised with the principles of a good taxation such as equity, efficiency and low transaction cost. As a result, efforts were made to look for an alternative tax regime for both increasing revenue collection and ensuring equity and efficiency. Chelliah Committee (1991) recommended for structural changes in both direct and indirect taxes and there is also opinion that along with indirect taxes, direct tax reform too should be one of the main agendas of policy reforms (Piketty and Quian, 2009). During 2003-04, the Government of India went for further simplification and rationalisation of indirect taxes with the recommendation of Task Force Committee chaired by Dr. Vijay Kelkar. The uniform indirect tax namely "GST" is one of the recommendations of this Task Force Committee. Since then, GST has remained one of the major agendas in tax system reform process in India. Proper shaping of GST started in 2006-07 and finally, as stated earlier, on 8th August 2016, the Lok Sabha approved of "Goods and Services Tax (GST)" Bill after Rajya Sabha passed it through $122^{\text {nd }}$ Amendment of the Constitution. No other tax received such hype in the history of the Indian tax system. Mentioning the "Quit India" movement of August 8, 1942 invoked by the Father of the Nation, Mahatma Gandhi, the present Indian Prime Minister declares on the same day that GST will "liberate Indians from tax terrorism".

\footnotetext{
${ }^{3}$ A cascading tax is a turnover tax that is applied at every stage of production, without any deduction for the tax paid at earlier stages. As a result, such cascading may create distortion of the tax regime (Kleen, 2012).
} 
According to the current Finance Minister, Mr. Arun Jaitley, GST is "one nation, one tax" system.

The GST is applicable to all goods and services except for alcohol for consumption and five specified petroleum products (Crude, Petrol, Diesel, ATF and Natural Gas) with comprehensive and continuous chain starting from consumers to final retailers with benefits at each stage. It is applicable to each stages of value added through a tax credit mechanism. The provision of taxing each stages of value added would eliminate the scourge of 'double taxation'. It is expected that GST will increase tax revenue, reduce transaction cost, promote equity, enhance transparency and thereby, lessen tax evasion and avoidance as well as increase tax domain. Government is expecting an increase of GDP by $2-2.5 \%$ in the GST regime to accelerate investment and jobs in the coming years. However, critics argue that the euphoria over GST camouflages the deadly assault to tax policy as a means of promoting equity and efficiency. It is feared that GST may generate cascading effect which earlier occurred to MODVAT and GST has been conferred the title of a hybrid of existing VAT (Sridhar, 2016).

\section{Controversy over GST claim}

Much has been debated about the advantages of GST in terms of increasing revenue, reducing cost, achieving equity and efficiency parameter of a good tax system. In this section, I make an attempt to discuss the pros and cons of such claims.

\section{Revenue generation}

Government of India is expecting more revenue from GST for its wide coverage with minimum leakage. Chadha et al. (2010) estimates that introduction of GST will increase India's GDP somewhere between $\$ 12.43$ billion to $\$ 12.60$ billion (from $0.09 \%$ to $1.7 \%$ ) based on $2008-09$ indices ${ }^{4}$. To increase revenue, the income tax department, Government of India suggests including agricultural income under GST

\footnotetext{
${ }^{4} 1$ dollar $=? 66.58$ as on 06.10 .2016
}

regime. They estimate that $10 \%$ tax on 'declared' agricultural incomes will yield ?2000 trillion. However, the Finance Minister out rightly rejects the idea on the ground that large farm-based income is rare in India and dishonest tax payers may show illegal money in their possession as agricultural income. Although tobacco and tobacco products along with luxury goods will be highly taxed, there is no tax on consumption of alcohol under GST. This action is justified on the ground that it will allow states to levy specific taxes for creation of their own revenue. Exemption of alcohol from GST is often questioned on the ground that it may generate negative externality and narrows down the scope of revenue collection. There is every reason to include alcohol under GST for significant under-reporting of alcohol sales and inter-state smuggling due to rate arbitrage (Bhaskar and Nath, 2015).

To avert the regressive nature of GST on consumption there will be a negative list of essential goods (though the list has not been finalised as yet. However, it is expected that the common items that would be exempted would include bread (excluding pizza), eggs, milk, fresh vegetables, betel leaves, cereals, books, salt, and the national flag) where no tax will be levied but it is expected that the list would incorporate more items. All other remaining products would be taxed to a revenue neutral rate (RNR) which is expected to be recalculated frequently. Critics are sceptical about the RNR calculation. Revenue collection by a state depends on several complex and volatile factors like trend of revenue collection over time, relative tax buoyancy and the level of consumption of goods and services. Therefore, frequent recalculation of RNR will not be feasible. Even if one assumes accuracy in RNR calculation, the provision of compensation to some states is a form of redundancy insurance guarding against the under and over estimation of the same (Bhasker and Nath, 2015).

\section{Transaction costs}

Multiple types of taxes on same good across different states and their different pattern within the country increases transaction cost 
and decreases export competitiveness of goods and services (Mukherjee, 2015). World Bank report reveals India's position in the easiness of doing business ranking is intensely poor (130 out of 198 countries) (World Bank, 2015a). Moreover, delay in the checkpoints at state/city due to many more formalities results in higher transit time and logistics cost. Truck in India spends around $60 \%$ of their time of travel in checkpoints. Truck drivers clock an average of 250-280 km per day in India which is much below than world average (400 km per day) and USA (700 kms per day) (Krishna, 2016). These add $13-14 \%$ value of the goods in India in comparison to $6-8 \%$ in other developing/developed countries (World Bank, 2015b).

Although GST is a destination-based tax on consumption, it cannot be expected that GST will minimise transaction costs as the bill proposes a levy of $1 \%$ tax rate for inter-state trade on all goods and services in addition to normal tax. Bhasker and Nath (2015) argue that this type of flaws will promote flow of cheaper goods from neighbouring countries under the purview of "Free Trade Agreements" policy. In addition to it, non-inclusion of certain fossil fuels and electricity under GST purview will have a cascading tax-effect and it will adversely affect competitiveness of domestic industries in international markets (Mukherjee and Rao, 2015).

\section{Equity}

As poor people make more consumption expenditure than richer ones, taxes on consumption and any increase in it will aggravate both horizontal and vertical inequality (Rajkumar and Krishnaswamy, $2015)^{5}$. The GST structure proposes an exemption of 100 items of local importance from earlier 390 items. It means that this proposition will increase the price of other nonexempted commodities earlier exempted in the

\footnotetext{
${ }^{5}$ The fiscal imbalance between two levels of government (Centre and States or Provinces) is called vertical fiscal imbalance while fiscal imbalance between the governments at the same level is called horizontal fiscal imbalance (Sharma, 2012; see also, Belinga et al., 2014).
}

central and state lists under VAT. In other words, the GST reveals a more regressive nature of Indian tax system against the socalled proposed equity in tax structure. Rather, one cannot expect more items under exemption list because both compensation to state and low rate of GST (as campaigned by the Central Government), are not compatible with further exemption.

From state's point of view, the consumption tax may be a curse for those states that manufacture products, which they do not consume. However, it will be beneficial for those states who consume it. So, earlier if a state was gaining revenue from manufacturing products in their states, now they will be losing due to final sales of their products to other states. Though the interests of the manufacturing states will be protected through imposition of the additional tax, it will generate cascading of taxes (Mukherjee, 2015).

In case of exports, the state has to refund the manufacturer on a proportionate basis of the portion of GST that has been paid by the company. It will adversely affect that state's revenue pool, which may challenge the Prime Minister's "Make in India" initiative that was launched on 25 September 2014. The aim of 'Make in India' initiative is to make India the biggest manufacturing and export hub. Under GST regime, manufacturing state may not be interested to become a member of manufacturing and export hub as they have to forgo a portion of their earnings (that could have earned at the present tax system) to the final consumption state and the company. For example, Tamil Nadu is worried about massive loss under GST. This is because Hyundai, one of the biggest car-manufacturing companies, manufactures cars in Tamil Nadu but sells only $10 \%$ of its product within the state while $40 \%$ of its products are sold in other states and the remaining $50 \%$ are exported.

\section{Tax Evasion}

Since GST will have proper records with a paper trail, which can be accessed by income tax department, there will be less scope of domestic black money. But people have 
reservations on this issue. One of the major sources of tax evasion and avoidance in formal domain is the real estate sector where misinvoicing, transfer pricing are done through informal way. Interestingly, the real estate sector is left out of the GST purview.

\section{Concluding Remarks}

Besides the equity and efficiency issues discussed above, effective implementation of GST may be impaired by some institutional hegemony. For example, one can take the GST Council (GSTC) which is constructed by government to finalise RNR and to resolve any dispute emerging from it among states. In this council, the central government can easily veto any decision if it differs from states. To implement GST on 1st April 2017, GSTC is planning to finalise the exemption list and the RNR with a favourable consensus from all the stakeholders within a short period of time. In the first meeting on 12th September 2016 members of the GSTC advocates for large-scale awareness programs especially for small-scale traders to generate awareness on the complex procedures and processes of GST regime. In addition, effective implementation of social safety nets remains paramount to curb the negative effect of GST on consumption by poor (Subramanian, 2015; Mathu, 2016). In spite of difficulties, both centre and states have to work together because Government of India cannot afford the failure of GST if the promises of higher expenditure on education, free housing, urbanisation and infrastructure (including building of smart cities) have to be fulfilled.

\section{References}

African Revenue Service. Available at: http://www.treasury.gov.za/publication s/tax\%20statistics/2015/TStats\%202015 \%20Inside\%20WEB.pdf (accessed 15 September 2016)

Belinga,V., Benedek,D., Mooij, R. de and John Norregaard, J. (2014). Tax Buoyancy in OECD Countries, IMF Working Paper, WP/14/110, Fiscal Affairs Department, available at: http://www.ibet.com.br/download/Tax
\%20Buoyancy.pdf

(accessed

20

September 2016)

Bhaskar, V. and Nath, K. P.S.S. (2015). What Ails the Implementation of the Goods and Services Tax? Economic \& Political Weekly, 12 September, Vol. I no. 37, pp.12-14

Chadha, R., Tandon, A., Ashwani, Mohan, G. and Mishra, P.P. (2010). Moving to Goods and Services Tax in India: Impact on India's Growth and International Trade, National Council of Applied Economic Research, December 2009, pp. 1-87, available at: fincomindia.nic.in/writereaddata/html_ en_files/oldcommission.../report28.pdf (accessed 10 September 2016)

Krishna, G.D. (2016, 21 August). A Step Closer to GST, The Assam Tribune, (p.6)

Kleen, M. (2012). Targeting, Cascading, and Indirect Tax Design, Raja Chelliah Memorial Lecture Series, National Institute of Public Finance and Policy, New Delhi, available at: http://www.nipfp.org.in/media/mediali brary/2013/09/Michael.pdf (accessed 20 September 2016)

Mukherjee, S. (2015). Present State of Goods and Services Tax (GST) Reform in India, Working Paper No. 2015-154, National Institute of Public Finance and Policy, pp.1-14, available at: http://www.nipfp.org.in (accessed 12 September 2016)

Mukherjee, S. and Rao, R.K. (2015). Designing GST for India Inclusive of Petroleum, Natural Gas and Electricity: Policy Options, NIPFP One Pager No. 006 (2014), available at: http://works.bepress.com/sacchidanan da_mukherjee/64/ (accessed 10 September 2016)

Muthu, K. (2016). Goods and Service Tax: Crouching Tiger or a Jackal in Disguise? Unpublished dissertation, Master of Science in Contemporary India, 
University of Oxford, pp. 1-83, available at:

www.southasia.ox.ac.uk/.../Muthu,\%20

K\%20MSc\%20Dissertation\%20June\%202

016 (accessed 12 September 2016)

National Treasury, (2015). Tax Statistics. [online] Pretoria: National Treasury and South

Picketty, T. and Qian, Q. (2009). Income Inequality and Progressive Income Taxation in China and India, 1986-2015, American Economic Journal: Applied Economics, 1(2), pp.53-63, available at http://www.aeaweb.org/articles.php?d oi=10.1257/app.1.2.53 (accessed 12 September 2016)

Rajkumar, J.D. and Krishnaswamy, R. (2015). Surge in Union Government Revenues Indirect Tax Collection Leads Growth, Economic \& Political Weekly, 12 December, Vol. I no. 50, pp.82-85 EP

Sharma, C.K. (2012). Beyond Gaps and Imbalances: Re-structuring the Debate on Intergovernmental Fiscal Relations, Public Administration, 90 (1), 99-128, DOI:10.1111/j.1467-9299.2011.01947.x

Sridhar, V. (2016) A Killer Tax, Frontline, 2 September, Vol. 33, no. 17, pp.45-48, (ISSN 0970-1710)

Subramanian, A. (2015). Report on the Revenue Neutral Rate and Structure of Rates for the Goods and Services Tax (GST). [online] New Delhi: Ministry of Finance, available at:

http://www.finmin.nic.in/the_ministry/ dept_revenue/report_revenue_neutral_ rate.pdf. (accessed September 9, 2016)

World Bank, (2015a). Ease of Doing Business Index (1=most business-friendly regulations) |Data | Table. [online] Data.worldbank.org, available at :http://data.worldbank.org/indicator/IC. BUS.EASE.XQ (accessed 10 September 2016)

World Bank, (2015b). Goods and Services Tax Transport and logistics (T\&L) sector. [online] $P W C$ available at: https://www.pwc.in/assets/pdfs/public ations/2015/goods-and-servicestaxtransport-and-logistics-sector.pdf (accessed 10 September 2016)

\section{About the Author}

In 2004, Dr. Mahanta obtained his PhD in Economics from the Indian Institute of Technology (IIT) Guwahati. He joined the Department of Economics, Gauhati University as an Assistant Professor in 2005. During 201415, Dr. Mahanta pursued his postdoctoral research in risk and vulnerability at Sam Houston State University, Texas, USA. His field of interests include environmental, natural resources and health economics. He has authored a number of articles and presented papers in both national international conferences. His papers have been published in Elsevier and Springer journals. 